\title{
The Structure and Distribution of Household Wealth in Australia*
}

\author{
Bruce Headey, Gary Marks and Mark Wooden \\ Melbourne Institute of Applied Economic and Social Research \\ The University of Melbourne
}

Melbourne Institute Working Paper No. 12/04

ISSN 1328-4991 (Print)

ISSN 1447-5863 (Online)

ISBN 0734031548

\begin{abstract}
July 2004
This paper reports on research being conducted as part of the research program, "The Dynamics of Economic and Social Change: An Analysis of the Household, Income and Labour Dynamics in Australia Survey". It is supported by an Australian Research Council Discovery Grant (DP0342970). The paper uses the data in the confidentialised unit record file from the Department of Family and Community Services' (FaCS) Household, Income and Labour Dynamics in Australia Survey, which is managed by the Melbourne Institute of Applied Economic and Social Research. The findings and views reported in the paper, however, are those of the authors and should not be attributed to either FaCS or the Melbourne Institute. The authors also thank Diana Warren and Simon Freidin for research assistance and Marion Kohler and her colleagues at the Reserve Bank of Australia for their work in deriving imputed values for missing cases.
\end{abstract}

Melbourne Institute of Applied Economic and Social Research

The University of Melbourne

Victoria 3010 Australia

Telephone (03) 83445330

Fax (03) 83445630

Email melb-inst@unimelb.edu.au

WWW Address http://www.melbourneinstitute.com 


\begin{abstract}
2002 saw the first large-scale survey of household wealth carried out in Australia since World War I. Conducted as part of the second wave of the Household, Income and Labour Dynamics in Australia (or HILDA) Survey, it covered all main components of asset portfolios and debts. This paper uses these data to provide an overview of the structure and distribution of household wealth in Australia, providing estimates of the mean and median levels of household wealth by type of asset or debt, and estimates of the degree of inequality of wealth holdings. The data confirm that wealth is very unequally distributed, with the bottom half of the distribution owning less than 10 per cent of total household net worth (assets less debts), while the wealthiest 10 per cent account for 45 per cent of total net worth. The paper also includes an analysis of the factors associated with household wealth that indicates that wealth is significantly related to a range of factors including age, country of birth, parental occupational status, education, marital status, working hours, income, selfreported savings behaviour, a willingness to take risks and even various lifestyle behaviours, such as smoking and alcohol consumption.
\end{abstract}




\section{Introduction}

Wealth matters enormously both to individuals and to the national economy. First, wealth confers a level of economic security, enabling individuals to cope when incomes fall. Second, the capacity to borrow and thus both spend for today and invest in the future is directly dependent on the level of ownership of assets. Third, wealth directly generates income. It thus should not be surprising that major changes in the structure of wealth, such as the rapid rise in the household debt to income ratio over the past decade, ${ }^{i}$ attract considerable attention from policy-makers, financial institutions and the wider community. However, despite the obvious importance of wealth for a range of economic and social questions, we actually know very little about the wealth holdings of individual Australian households. While the Australian Bureau of Statistics (ABS) has, since the mid-1990s, published a household balance sheet as part of the Australian System of National Accounts, individual- or householdlevel data on assets and debts have not been collected. As a result, estimates of the structure and distribution of wealth at the household level have typically had to be imputed on the basis of the income flows generated by selected assets. Moreover, the income data typically have to be drawn from a variety of different sources.

In 2002, however, as part of the second wave of the Household, Income and Labour Dynamics in Australia (or HILDA) Survey, detailed data were collected on the assets and debts held by a large national sample of Australian households. These data thus potentially enable us to focus on the differing asset portfolios of richer and poorer households, and to answer a range of distributive questions. For example, in what form do Australian households accumulate wealth? How unequal is the distribution of wealth? How does the distribution of wealth compare with, and how closely does it depend on, the distribution of income? To what extent is inequality in the wealth distribution simply a function of the life cycle? And how do levels of wealth vary with household characteristics such as the age, marital status and education levels of the household members?

Answering such questions is the principal objective of this paper. After briefly reviewing recent research into the measurement and structure of household wealth in Australia and then introducing the data, the paper presents, in Section IV, summary statistics on the composition of household wealth. This is followed by the presentation 
of evidence on the extent of inequality in the distribution of household wealth. We next examine, in Section VI, how net worth (that is, assets less debts) varies with different household characteristics, presenting results from simple models that regress various household characteristics against net worth. Finally we conclude by identifying gaps in our knowledge of wealth dynamics.

\section{Previous Research}

Many readers might be surprised to learn that the first serious attempt at collecting wealth data from Australian households occurred as long ago as 1915. Moreover, this collection was based on data collected not from a population sample but from a census - the 1915 War Census conducted by the Commonwealth Bureau of Census and Statistics (see Soltow 1972). Since that time there has been only one other significant attempt at collecting wealth data directly from Australian households - a university-based survey conducted over the period 1966-1968 (see Podder and Kakwani 1976). The relatively small sample size - just 2757 households - combined with high rates of non-response, however, has tended to undermine the results from this survey. ${ }^{\text {ii }}$ Indeed, according to Piggott (1984, p. 255), this survey seriously understated total wealth, with only about two-thirds of actual total personal wealth captured.

Since that time we are unaware of any other survey-based study that has directly measured the wealth holdings of individual Australian households (though there have been many surveys of housing wealth). Instead, estimates of the distribution of wealth have generally been derived from more indirect methods. For much of the $20^{\text {th }}$ century the most common method involved imputing an overall distribution on the basis of probate returns, or estate data. ${ }^{\text {iii }}$ Such methods, however, are problematic for a number of reasons. Most importantly, the incentive to avoid and minimise estate duties invariably meant wealth was understated and, since avoidance is more likely among the very wealthy, inequality overstated in estate data. In any case, these data only existed as a by-product of the imposition of taxes on estates, and thus once estate duties were abolished, these data sources ceased to exist.

In recent decades, researchers interested in the distribution of wealth have been forced to rely on what is known as the investment income method. That is, the 
size of different wealth components is estimated based on the size of the income flows generated by different assets. Dilnot (1990), for example, used information from the 1986 Income Distribution Survey (IDS) conducted by the ABS to produce estimates for households of investment income. Combined with estimates of net housing wealth collected directly from households in the IDS, he was then able to derive an estimate of the distribution of household wealth. ${ }^{\mathrm{iv}}$ This approach has been extended by researchers at the National Centre for Social and Economic Modelling (NATSEM) who have provided more recent estimates of the distribution of wealth, covering the years 1986, 1993 and 1996, using both a more complete list of assets (notably the addition of superannuation) and more sophisticated methods for deriving the rate of return to different assets (see Bækgaard 1998a; Bækgaard 1998b; Kelly 2001). Most recently, the ABS, using a variety of data sources, have developed household-level estimates for wealth for the period 1994-2000 which seemingly cover all forms of assets and debts held by households, rather than just a subset (ABS 2002; Northwood et al. 2002).

The main conclusions from these previous studies are fourfold. First, the major component of household wealth in Australia is housing, followed by superannuation. The ABS studies, for example, suggest that, in the year ended 30 June 2000, dwellings — both owner-occupied and rental investments - and superannuation accounted for 46 per cent and 21 per cent of total household assets respectively (Northwood et al. 2002, p. 27).

Second, the distribution of wealth in Australia is very unequal. The richest ten per cent of households are typically reported to own close to 45 per cent of all wealth owned by households (Bækgaard 1998a; Northwood et al. 2002). In contrast, the bottom three deciles have no wealth at all. Indeed, the bottom decile often shows negative wealth - that is their debts exceed their assets.

Third, while inequality may be high, both the NATSEM and ABS studies suggest no increase in wealth inequality since the mid-1980s. Further, wealth inequality has probably declined since 1915 when the wealthiest five per cent of households owned two-thirds of total assets and the wealthiest 20 per cent of households owned 90 per cent (Kelly 2001; Soltow 1972). ${ }^{v}$ Soltow (1972), for example, calculated that the Gini coefficient in 1915 for personal wealth was 0.86 . In comparison, estimates for the late 1990s suggest a much smaller Gini (and thereby a 
less unequal distribution) of 0.64 (Kelly 2001). That said, it is worth noting that unlike the 1915 data, the more recent estimates are derived from sample survey data, and generally sample sizes are insufficient to adequately represent the most wealthy (see Juster et al. 1999). As a result, we expect sample survey data to understate the true level of wealth inequality.

Fourth, the level of household wealth is associated with characteristics of households and its members, such as age, marital status, education and income. Thus net worth has been found to be relatively low among 15 to 24 year olds, but increases substantially with each successive age cohort before peaking in the 55 to 64 year old cohort, after which it declines (Bækgaard 1998a; Northwood et al. 2002). Wealth also tends to be greater for couples, a result which, as Kelly (2001, p. 22) has shown, holds for all age groups. Such findings are to be expected given couples have two incomes to service mortgages and contribute to superannuation. They also may have assets prior to partnering. More surprising, Kelly (2001) also found that couples with children accumulate similar amounts of wealth to couples without children. This suggests that children do not substantially reduce wealth, implying that families adjust their income and expenditure patterns to overcome the costs of children. Not unexpectedly, wealth has also been found to be correlated with income. Bækgaard (1998a), for example, found that in the early 1990s the average wealth of the top income decile was five to six times that of the bottom three deciles. That said, the distributions of income and wealth are still quite different, with only small increases in wealth across the bottom five income deciles (Northwood et al. 2002, p. 33). The association between income and wealth is further reduced by substantial numbers of asset-rich but income-poor households, which Bækgaard (1998a) suggests comprise the self-employed and retirees. Finally, the level of education has also been found to be associated with wealth. Kelly (2001, pp. 24-25), for example, reported that degrees and diplomas were associated with greater wealth, and the differences were substantial among older age groups. 


\section{Data}

(i) The HILDA Survey

As already noted, the data used here come from the second wave of the Household, Income and Labour Dynamics in Australia (HILDA) Survey, conducted in 2002. Described in more detail in Watson and Wooden (2002a), the HILDA Survey is a household panel survey funded by the Commonwealth through the Department of Family and Community Services. It began with a large national probability sample of households, and involved personal interviews with all household members aged 15 years and over. In wave 1, interviews were obtained at 7682 households, which represented 66 per cent of all households identified as in-scope. This, in turn, generated a sample of 15,127 persons eligible for interview, 13,969 of whom were successfully interviewed.

In 2002 all responding households from wave 1 were re-contacted. Interviews were again sought with all household members aged 15 years or over, including persons who did not respond in wave 1, as well as any new household members. In total, interviews were completed with 13,041 persons from 7245 households. Of this group, almost 12,000 were respondents from wave 1, which represented almost 87 per cent of the wave 1 individual sample.

Like all surveys, the HILDA Survey suffers from sampling errors, and as a result the characteristics of the sample do vary from the population it represents (see Watson and Wooden 2002b). The data include weights to 'correct' for these biases. In addition, in wave 2 the weights used adjust for further biases arising from selective attrition. $^{\mathrm{vi}}$

The coverage of the survey is extremely broad, but with a focus on household structure and formation, income and economic well-being, and employment and labour force participation. In wave 2, with additional funding from the Reserve Bank of Australia (RBA), a special module of questions on household assets and debts was included.

\section{(ii) Measuring Wealth}

Like all previous research concerned with the measurement of private wealth, attention is restricted to those components of wealth which are most easily observed and measured. Specifically, attention is largely restricted to current physical and 
financial assets, as well as any financial liabilities. No attempt is made to account for human capital, which can be expected to be associated with increased rates of accumulation of assets in the future, nor of wealth derived from access to communal assets.

Most of the questions about assets and debts were asked at the household level and answered by one person on behalf of the entire household. These questions covered housing and property, business assets and liabilities, equity-type investments (e.g., shares, managed funds) and cash-type investments (e.g., bonds, debentures), vehicles and collectibles (e.g., art works). However, some questions about assets and debts - those that it was felt could not be reported accurately by one person on behalf of all - were asked of individuals. These included questions about superannuation, bank accounts, credit cards, HECS debt and other personal debt. In answering all questions, respondents were asked to provide exact dollar amounts. However, bands were offered to those who could not supply a more precise estimate of their superannuation holdings; a particularly difficult topic.

Note that as in the National Accounts, since unincorporated enterprises are not legal entities separate from their owners, the assets used in such enterprises are treated as belonging to individual household members.

Wealth, even when restricted to physical and financial assets (and liabilities), is difficult to measure in surveys and, when it has been attempted overseas, has been associated with both high item non-response rates and under-estimates of national wealth. Estimates of total net worth from the Panel Study of Income Dynamics, a major US household panel survey, for example, have been reported to understate Flow of Funds data from the Federal Reserve of between 22 and 28 per cent (Juster et al. 1999, Table 1, p. 256). This last result is partly due to under-reporting and, as noted previously, partly because the very wealthy households, who own a vastly disproportionate share of total wealth, are invariably under-represented in surveys. Indeed, an equal probability sample will always be badly placed to measure wealth given that wealth is so concentrated at one end of the distribution.

The HILDA Survey was clearly not immune from these difficulties. For example, despite item response rates on most wealth components of over 90 per cent, we were only able to directly compute total net household wealth for 61 per cent of all 
responding households. ${ }^{\text {vii }}$ The data file, however, includes a set of wealth variables where most missing values have been replaced by an imputed value. ${ }^{\text {viii }}$ Imputation of missing values is essential, since to omit cases with missing data would have introduced a bias against larger and, on average, wealthier households, in which it is harder to get every eligible respondent to participate.

As a guide to the usefulness of the wealth data provided by the HILDA Survey, Table 1 reports a comparison of the HILDA Survey estimates of household assets, debts and net worth with the national aggregates compiled by the ABS as part of the Australian System of National Accounts. Further, we also report estimates regularly reported by the RBA given that these tend to depart from the ABS figures in one key respect. All figures are in billions of dollars and the HILDA Survey estimates have been weighted to reflect the total population of private households.

TABLE 1

Aggregate Household Wealth: HILDA Estimates and 'Official' Estimates Compared, 2002 (\$ billion)

\begin{tabular}{lccc}
\hline & ABS $^{\mathrm{a}}$ & RBA $^{\mathrm{b}}$ & HILDA $^{\mathrm{c}}$ \\
\hline Financial assets & 1236.7 & 1084 & 1125.1 \\
Non-financial assets & $1955.4^{\mathrm{d}}$ & 2391 & 2440.3 \\
Total assets & 3192.1 & 3474 & 3565.4 \\
Financial debts & 630.8 & 640.5 & 516.5 \\
Net worth & 2561.3 & 2833.5 & 3048.9 \\
\hline
\end{tabular}

Notes: a. All figures reported are intended to represent an average of the September 2002 and December 2002 quarters. In addition to households, the assets and liabilities of nonprofit organisations are also included.

b. The RBA figures reported here apply to the December quarter of 2002 .

c. Figures from the HILDA Survey were collected over the period August 2002 to March 2003, but with October 2002 being the median observation point. All data are weighted and include imputations for missing values. The scope of the survey excludes households living in very remote parts of Australia.

d. The National Accounts only reports financial year figures for non-financial assets. We have thus interpolated an estimate based on the figures reported for 30 June 2002 and 30 June 2003. The estimate reported here includes an estimate of consumer durables, which is a memorandum item to the National Balance Sheet.

Sources: ABS data derived from Financial Accounts (ABS cat. no. 5232.0), Table 15, and Australian System of National Accounts, 2002-03 (ABS cat. no. 5204.0), Tables 16 and 50.

RBA data taken from Statement of Monetary Policy, various issues. 
At first glance the figures reported in Table 1 suggest that, compared with the two Government sources, the HILDA Survey has overstated assets but understated debts. An overstatement of assets would be surprising given our expectation that an equal-probability sample survey should result in an inadequate representation of the wealth holdings of the very wealthy. Differences of inclusion and exclusion among the different sources, however, make comparisons far from straightforward. Such differences are summarized in Table 2.

TABLE 2

Aggregate Wealth Sources: Summary of the Differences in Scope

\begin{tabular}{lccc}
\hline Asset Type & ABS & RBA & HILDA \\
\hline Financial assets & & & \\
$\quad$ Deposits & $\checkmark$ & $\checkmark$ & $\checkmark$ \\
Bonds, etc. & $\checkmark$ & $\checkmark$ & $\checkmark$ \\
Equities & $\checkmark$ & $\checkmark$ & $\checkmark$ \\
Unfunded superannuation & $\checkmark$ & $\times$ & $\checkmark$ \\
Pre-paid insurance premiums & $\checkmark$ & $\times$ & $\times$ \\
Non-financial assets & & & \\
Vehicles & $\checkmark$ & $\checkmark$ & $\checkmark$ \\
Other consumer durables & $\checkmark$ & $\checkmark$ & $\times$ \\
Housing and property & $\checkmark$ & $\checkmark$ & $\checkmark$ \\
Business & $\checkmark$ & $\times$ & $\checkmark$ \\
Collectibles & $\times$ & $\times$ & $\checkmark$ \\
\hline
\end{tabular}

Note: $\checkmark$ indicates that component is included in estimates of net worth while $X$ indicates it is not.

First, we compare the estimates of financial assets. Table 2 shows that the $\mathrm{ABS}$ and the RBA only differ in how they treat unfunded superannuation and pre-paid insurance; the RBA excludes them whereas the ABS do not. Conceptually the HILDA Survey falls between the two, including unfunded superannuation but excluding prepaid insurance premiums, and as it turns out the HILDA estimate does lie between the ABS and RBA estimates. If we adjust the HILDA data by adding the ABS estimate of pre-paid insurance premiums - just over $\$ 28 \mathrm{~b}$ - we find that the HILDA estimate is about 93 per cent of the ABS estimate. Thus, as expected, the HILDA Survey understates the volume of financial assets. The size of that understatement, however, is relatively modest. 
Turning to non-financial assets, Table 2 suggests that it is the RBA source which should be the outlier given its exclusion of business assets. The figures reported in Table 1, however, indicate that the HILDA Survey estimate of non-financial assets is actually much closer to the RBA estimate than it is to the ABS estimate. The most significant source for this difference is property values. The RBA estimated property to be worth $\$ 2252 \mathrm{~b}$ at the end of December 2002 which exceeds the total value of all non-financial assets reported in the National Accounts. Indeed, the HILDA Survey estimates are much more in line with the RBA mainly because the aggregate property value derived from the self-reports in the HILDA Survey - $\$ 1932 b-$ is also much larger than the valuation derived by the ABS. Overall, once we take account of the marked differences in the composition of the assets measured, the HILDA Survey estimates are reasonably comparable to RBA estimates, but as expected, are again on the low side - the HILDA survey estimate of the value of property is only 86 per cent the size of the RBA estimate. The lower RBA estimate reported in Table 1 is simply a function of the exclusion of business assets. The much lower ABS estimates, on the other hand, are mainly a reflection of the marked difference in the way property and housing values are derived.

It is also worth noting that the ABS estimate of business assets is likely to be much lower than the HILDA Survey estimate. While not separately identified in the National Accounts, Northwood et al. (2002) report a business asset valuation of just $\$ 124$ b for 30 June 2000. By comparison, the HILDA Survey estimate for 2002 is $\$ 339$ b. The main reason for this difference is conceptual; the HILDA Survey asks respondents to estimate the market value whereas the ABS reports the 'book' value, and typically the book value of a business is only about half its market value (Webster 2000).

The final comparison relates to debts. Here the HILDA estimate is much (20 per cent) lower than the official sources. In retrospect we suspect the HILDA questionnaire may not have included enough questions on separate types of debt. As noted above, the HILDA Survey enables household debt to be separated into five categories: housing debt, business debt, HECS debt, credit card debt, and 'other' debt. It might have been preferable to ask additionally about overdrafts (excluding housing), vehicle debt, hire purchase, gambling debts and so on (see Juster et al. 1999). Even so, there may be some irreducible tendency for respondents to under- 
report debt, partly for social desirability reasons. We also believe that relative to official sources, credit card debt will be understated in the HILDA Survey data. Those respondents who said they routinely paid up in the first month and so incurred no interest charges were recorded as having no credit card debt. By contrast, the official sources record card liabilities owed by the nation's households at one moment in time.

\section{The Composition of Household Wealth}

We now begin our presentation of data from the HILDA Survey with a summary of the composition of household wealth. Table 3 thus reports mean and median assets, debts and hence net worth, and also the percentage contribution which each type of asset and debt makes to total holdings. Because the distribution of wealth is highly skewed, medians give a better idea of the typical household's wealth than the mean. Note, however, that rather than report the simple median, the medians given here are for the median household in the $50^{\text {th }}$ and $51^{\text {st }}$ percentiles of net worth. We argue that this provides a better guide to the typical Australian household.

In the last quarter of 2002 the average household had a net worth of $\$ 404,300$, this being made up of $\$ 472,800$ of assets and $\$ 68,500$ of debts. However, these figures are skewed upwards by the wealth of a relatively small number of very wealthy households. The median or 'typical' household had assets of only about $\$ 270,000$ and a net worth of about $\$ 218,000$.

As is well known, Australians' asset portfolios are dominated by housing. The HILDA Survey data confirm this with housing and other property constituting almost 55 per cent of all household assets and close to 75 per cent of the assets of the median household. ${ }^{\text {ix }}$ Indeed, just over two-thirds of all Australian households owned or were buying their own home while 16.7 per cent had a stake in other property as well (a holiday home or investment property). The latter figure is consistent with Taxation Office data which indicate that some 13 per cent of taxpayers report earning rental income in 2000/01, and imply rates of investment property ownership that are double that in the USA and more than six times the level in the UK (RBA 2003, p. 19). ${ }^{\mathrm{x}}$ 
TABLE 3

Overview: Assets, Debts and Net Worth per Household, 2002

\begin{tabular}{lccc}
\hline Type of Asset / Debt & $\begin{array}{c}\text { Mean } \\
(\$ 000)\end{array}$ & $\begin{array}{c}\text { Median } \\
(\$ 000)\end{array}$ & $\begin{array}{c}\text { \% of assets / } \\
\text { debts }\end{array}$ \\
\hline Assets & & & \\
Housing and other property & 256.2 & 200.0 & 54.2 \\
Pensions / superannuation & 77.1 & 27.3 & 16.3 \\
Businesses and farms & 44.9 & 0 & 9.5 \\
Equity investments (shares, & & & 6.6 \\
$\quad$ managed funds, etc.) & 31.4 & 0 & 4.6 \\
Bank accounts & 21.5 & 4.1 & 4.0 \\
Vehicles & 19.0 & 10.3 & 3.8 \\
Other assets & 17.9 & 0 & 68.4 \\
All non-financial assets & 323.6 & 217.8 & 31.6 \\
All financial assets & 149.2 & 51.5 & $100.0^{\mathrm{c}}$ \\
Total assets & 472.8 & 270.5 & \\
Debts & & & 75.0 \\
Housing and other property & 51.4 & 47.7 & 9.9 \\
Businesses and farms & 6.8 & 0 & 1.9 \\
HECS (student debt) & 1.3 & 0 & 1.5 \\
Credit cards & 1.0 & 0 & 10.2 \\
Other debts & 7.0 & 0 & $100.0^{\mathrm{c}}$ \\
Total debts & 68.5 & 53.2 & \\
Net worth & 404.3 & 218.3 & \\
\hline
\end{tabular}

Notes: a. The reported medians are for the median household in the $50^{\text {th }}$ and $51^{\text {st }}$ percentiles of net worth, and not the median over the entire distribution.

b. Other assets include cash investments, trust funds, the cash-in value of life insurance and collectibles.

c. The sub-components do not sum to 100 because missing values for some of the subcomponents have not been fully imputed (see fn 8).

The second largest asset of most households is superannuation, which has become much more widely held, and somewhat more equally distributed in the last 15 years (Kelly 2001). Even so, the median household holds superannuation worth only about $\$ 18,000$, though this rises to $\$ 27,000$ once we focus on households in the middle of the wealth distribution. Other holdings of considerable value to some households are business assets and equity investments (such as shares, managed funds and listed property trusts). The median household holds no equities and of course does not own a business. However, the 41 per cent of households who do own equities average about $\$ 70,000$ worth (median $=\$ 15,000)$, and the average value of businesses (owned 
by 12.5 per cent of households) was about $\$ 291,000$ (median $=\$ 80,000)$. It should be noted, however, that equity investments are understated here since, in order to avoid double-counting, respondents were asked not to include superannuation in their calculation of equity holdings, and of course some superannuation is held in equities. Moving towards the bottom of the list of assets, the median household has a car worth about $\$ 10,000$ and just $\$ 4,500$ in the bank.

Household debt is mainly mortgages. The average property debt is about $\$ 51,000$, which is only slightly higher than the level held by the median household; $\$ 47,000$. Most households have very little or nothing in other forms of debt. Some might be surprised at the low levels of credit card debt, but note again that we only record as debt what was owed after the last payment made, and a majority of individuals with credit cards report paying off their entire balance. ${ }^{\mathrm{xi}}$

Finally, the data in Table 3 indicate that in most households non-financial assets dwarf financial assets. Most households thus lack liquidity. They have relatively little cash and certainly little that they can easily cash up if normal sources of market income are temporarily or permanently cut off, or if emergency expenditures are required. This means that in the absence of usual income sources, many households will be forced to rely primarily on government transfer payments. This is especially clear when one remembers that, until one retires, superannuation is not available and so, while classified as a financial asset, it is not in reality liquid for persons of pre-retirement age.

\section{$V$ The Distribution of Household Wealth}

\section{(i) The Overall Distribution of Net Worth}

In Australia, as in other Western countries, wealth is much more unequally distributed than income. The Gini coefficient for household net worth that is derived from the HILDA Survey data is 0.61 , which compares with a Gini of 0.43 for household gross incomes and 0.38 for household disposable incomes for the 20012002 financial year. The fact that wealth inequality is greater than income inequality is far from surprising, and reflects the greater dependence of wealth on savings as one ages. Wealth accumulates via both voluntary saving and compulsory superannuation, and these savings grow at compound interest as people age. Income, of course, also 
increases with age, but the gradient is nothing like as steep as wealth's compound interest gradient. The relationship between aging and wealth is explored in more detail below.

Table 4 provides more detailed data on the distribution of household wealth. More specifically, it shows the distribution of wealth among households by percentiles of net worth and by wealth component. Note that households are sorted into deciles on the basis of their total net worth, and thus the distribution of households is the same for all wealth components. However, for each component we also report a Gini coefficient which provides a summary of the degree of concentration of each wealth component independent of household net worth.

Focusing first on the final column in Table 4, we can see that among the 10 per cent of households that are the least wealthy, average net worth is actually negative, and that the bottom half of the distribution own less than 10 per cent of total household wealth in Australia. At the other end of the distribution, the wealthiest 10 per cent of households have an average net worth of just over $\$ 1.8 \mathrm{~m}$ (median holdings $=\$ 1.4 \mathrm{~m})$ and own 45 per cent of all household wealth. Interestingly, this latter figure is identical to the estimate reported by Kelly (2001) for 1998 even though the Kelly estimates are, with the exception of housing, largely derived using the investment income method. ${ }^{\text {xii }}$ As such, the HILDA Survey data provide added weight to Kelly's conclusion, based on a comparison with the earlier estimates for 1986 and 1993 that appeared in Bækgaard (1998a), that wealth inequality has remained stable since the mid-1980s.

Table 4 also reports more disaggregated information for the top decile which reveals that the wealthiest five per cent of households account for 31 per cent of total wealth. Again this figure is similar to that reported by Kelly (2001) for 1998 - 30 per cent - and by Bækgaard (1998a) for 1986 and 1993 - 30 and 29 per cent, respectively.

Though not revealed directly in Table 4, the HILDA Survey data also indicate that 8.8 per cent of households had, by 2002, a net worth of over a million dollars, with 11.2 per cent holding assets over the million mark. So, in a sense, about 1.8 million persons living in 638,000 Australian households could be described as millionaires. 
TABLE 4

The Distribution of Household Wealth by Component and by Wealth Percentile, 2002: Mean Values, \$000s (\%'s in parentheses)

\begin{tabular}{|c|c|c|c|c|c|c|c|c|c|c|}
\hline $\begin{array}{l}\text { Wealth } \\
\text { percentile }\end{array}$ & $\begin{array}{l}\text { Property } \\
\text { (net) }\end{array}$ & $\begin{array}{c}\text { Super- } \\
\text { annuation }\end{array}$ & $\begin{array}{c}\text { Equity } \\
\text { investments }\end{array}$ & $\begin{array}{c}\text { Businesses } \\
\text { (net) }\end{array}$ & $\begin{array}{c}\text { Bank } \\
\text { accounts }\end{array}$ & Vehicles & $\begin{array}{l}\text { Other } \\
\text { assets }\end{array}$ & $\begin{array}{c}\text { Credit card } \\
\text { debt }\end{array}$ & $\begin{array}{c}\text { Other } \\
\text { debt }\end{array}$ & $\begin{array}{c}\text { Household } \\
\text { net worth }\end{array}$ \\
\hline $1-10$ & $-1(0)$ & $3(0)$ & $0(0)$ & $-1(0)$ & $1(1)$ & $4(2)$ & $0(0)$ & $1(9)$ & $11(13)$ & $-6(0)$ \\
\hline $21-30$ & $18(1)$ & $19(2)$ & $3(1)$ & $1(0)$ & $7(3)$ & $12(6)$ & $2(1)$ & $1(12)$ & $7(8)$ & $55(1)$ \\
\hline $31-40$ & $61(3)$ & $25(3)$ & $5(2)$ & $3(1)$ & $9(4)$ & $13(7)$ & $3(2)$ & $1(14)$ & $5(7)$ & $114(3)$ \\
\hline $41-50$ & $113(6)$ & $32(4)$ & $6(2)$ & $5(1)$ & $10(5)$ & $16(8)$ & $5(3)$ & $1(11)$ & $6(7)$ & $181(5)$ \\
\hline $51-60$ & $170(8)$ & $42(6)$ & $10(3))$ & $4(1)$ & $17(8)$ & $18(10)$ & 7 (4) & $1(10)$ & $6(7)$ & $263(7)$ \\
\hline $71-80$ & 291 (14) & 98 (13) & $28(9)$ & $19(5)$ & $29(14)$ & 24 (13) & $18(10)$ & $1(9)$ & $8(10)$ & $503(13)$ \\
\hline $81-90$ & 388 (19) & $173(23)$ & $55(18)$ & 37 (10) & $37(17)$ & $27(14)$ & $21(12)$ & $1(7)$ & $10(12)$ & $740(18)$ \\
\hline $91-100$ & 777 (38) & $305(40)$ & $190(61)$ & $304(80)$ & 83 (39) & $49(26)$ & $111(62)$ & $1(9)$ & $18(22)$ & $1814(45)$ \\
\hline Total & $167(100)$ & $77(100)$ & $31(100)$ & $38(100)$ & $22(100)$ & $19(100)$ & $18(100)$ & $1(100)$ & $8(100)$ & $404(100)$ \\
\hline $91-95$ & $563(14)$ & $239(15)$ & $111(18)$ & 77 (10) & $51(12)$ & $38(10)$ & $54(15)$ & $1(4)$ & $15(9)$ & 1127 (14) \\
\hline $96-100$ & $990(24)$ & $372(24)$ & $269(43)$ & $532(70)$ & $115(27)$ & $60(16)$ & $167(47)$ & $1(5)$ & $21(13)$ & $2502(31)$ \\
\hline Gini & 0.49 & 0.68 & 0.78 & 0.75 & 0.78 & 0.52 & 0.78 & 0.56 & 0.65 & 0.61 \\
\hline
\end{tabular}


The level of concentration of asset ownership in the hands of the wealthiest households is particularly acute for business assets, with 80 per cent of net business wealth held by the richest 10 per cent of households. Equity investment and 'other assets' (cash investments, trust funds, life insurance and collectibles) are also highly concentrated in the hands of the rich, with 61 and 62 per cent respectively, owned by the wealthiest 10 per cent. On the other hand, vehicle ownership is far less concentrated, with the wealthiest 10 per cent responsible for only 22 per cent of vehicle worth. Between these two extremes lie property, superannuation and bank accounts, with between 38 and 40 per cent of these forms of wealth held by the wealthiest 10 per cent of households.

Note that the Gini coefficients suggest a slightly different picture, with the degree of inequality in business asset ownership slightly less than that for equities, bank accounts and 'other' assets. The relatively large Gini for these latter types of assets suggests that their ownership are just as highly concentrated as the ownership of business assets, but clearly that concentration is not as strongly correlated with household net worth. We can also see that while the degree of concentration of property and superannuation in the hands of the rich is very similar, the Gini coefficient on property ownership is much lower, suggesting that property ownership is not as closely correlated with net worth as is superannuation.

The most stark differences between concentration of ownership in general and concentration in the hands of the wealthy, however, occur with respect to credit card and personal debt. The Gini coefficients on both of these types of debt are in excess of 0.5 suggesting a relatively high degree of concentration. Nevertheless, the data also suggest that such debt is not held disproportionately by the wealthy. Indeed, 56 per cent of credit card debt is held by the least wealthy half of households while these households also hold 42 per cent of other personal debt.

\section{(ii) The Distribution of Net Worth and Cohort Differences}

Any analysis of wealth cannot avoid the fact that individuals accumulate wealth over their lifetimes, and hence wealth will vary substantially with age. While a serious analysis of this issue requires longitudinal data on wealth (something the HILDA Survey is expected to acquire in due course), cross-section data confirm that there is a clear age-based profile to wealth holdings. This can be seen in Table 5 
where we report mean and median values of total net worth, and its major components, by the age cohort of a household reference person. The definition of the reference person used here is similar to that used by the ABS in its Household Expenditure Survey. That is we apply the following criteria in order from top down until a unique person is selected. These criteria are:

- in a registered or de facto marriage (and still living together);

- a lone parent;

- the person with the highest financial year income; and

- the eldest person.

We, however, vary from these criteria in one respect. The lone parent criterion only takes priority over income if the children in the household are full-time students or are aged under 18 years of age.

Consistent with all previous research on the subject, the figures reported in Table 5 indicate that household net worth steadily increases with the age of the household reference person, peaking in the pre-retirement years of 55 to 64 years, before declining as households begin drawing down on their savings and assets in retirement. Table 5 also indicates that this finding is replicated for most asset types with perhaps the exception of vehicles, which are perhaps better thought of as consumption goods than capital goods (and thus wealth).

The other key conclusion that can be drawn from Table 5 is that even for the age group where wealth peaks, the wealth holdings of most Australian households are relatively modest. For the median household where the reference person is aged between 55 and 64 years, net worth is about $\$ 430,000$, which is well short of what is required to provide what the Association of Superannuation Funds of Australia recently defined as 'a comfortable lifestyle'. xiii Allegedly, this requires an income at current prices of just over $\$ 43,000$ a year, which in turn would require, in order to retire at age 60 , an investment portfolio of about $\$ 650,000$. Further, it must also be borne in mind that much of household net worth is tied up in the primary place of residence which is not so easily converted into cash. Indeed, if we assume that Australians desire to continue to live in the same home (admittedly a simplistic 
TABLE 5

The Distribution of Household Wealth by Component and by Age of Household Reference Person, 2002: Mean Values, \$000s (Medians in parentheses)

\begin{tabular}{|c|c|c|c|c|c|c|c|c|c|c|}
\hline $\begin{array}{l}\text { Age } \\
\text { cohort }\end{array}$ & $\begin{array}{l}\text { Property } \\
\text { (net) }\end{array}$ & $\begin{array}{l}\text { Super- } \\
\text { annuation }\end{array}$ & $\begin{array}{c}\text { Equity } \\
\text { investments }\end{array}$ & $\begin{array}{l}\text { Businesses } \\
\text { (net) }\end{array}$ & $\begin{array}{c}\text { Bank } \\
\text { accounts }\end{array}$ & Vehicles & Other assets & $\begin{array}{l}\text { Credit card } \\
\text { debt }\end{array}$ & Other debt & $\begin{array}{l}\text { Household } \\
\text { net worth }\end{array}$ \\
\hline $15-24$ & $31(0)$ & $8(3)$ & $3(0)$ & $2(0)$ & $3(1)$ & $10(4)$ & $4(0)$ & $0(0)$ & $8(3)$ & $54(8)$ \\
\hline $25-34$ & $80(10)$ & $36(16)$ & $9(0)$ & $25(0)$ & $9(2)$ & $17(12)$ & $12(0)$ & $1(0)$ & $9(2)$ & $180(80)$ \\
\hline $35-44$ & $189(110)$ & $70(30)$ & $17(0)$ & $42(0)$ & $14(3)$ & $22(15)$ & $19(0)$ & $1(0)$ & $10(0)$ & $367(216)$ \\
\hline $45-54$ & 279 (188) & $125(53)$ & $37(0)$ & $51(0)$ & $21(6)$ & $24(16)$ & $23(0)$ & $1(0)$ & $12(0)$ & $553(374)$ \\
\hline $55-64$ & $313(220)$ & $140(40)$ & $62(1)$ & $69(0)$ & $42(8)$ & $23(15)$ & $29(0)$ & $1(0)$ & $9(0)$ & $674(430)$ \\
\hline $65-74$ & $280(200)$ & $65(0)$ & $60(0)$ & $21(0)$ & $35(10)$ & $15(10)$ & $13(0)$ & $0(0)$ & $1(0)$ & 494 (309) \\
\hline $75+$ & $199(160)$ & $20(0)$ & $42(0)$ & $17(0)$ & $33(13)$ & $7(3)$ & $12(0)$ & $0(0)$ & $1(0)$ & $332(241)$ \\
\hline Total & $205(120)$ & 77 (18) & $31(0)$ & $38(0)$ & $22(5)$ & $19(12)$ & $18(0)$ & $1(0)$ & $8(0)$ & 404 (219) \\
\hline
\end{tabular}


assumption given that many Australians move into smaller, less expensive housing as they age), then the median household in the 55 to 64 year age group really has only about $\$ 240,000$ available for funding retirement, given the median net value of primary residences for the 55 to 64 year age group is $\$ 190,000$. Add the fact that many of the reference persons for households in this age bracket have already retired, then it seems safe to conclude that the dependence of most retirees on government to meet their consumption needs is not going to change any time soon.

The data also enable us to examine the within-cohort distribution of wealth. Table 6 thus shows how net worth differs across selected percentiles of the distribution of wealth for each 10-year age cohort. We also report two summary measures of inequality: the interquartile ratio comparing the $75^{\text {th }}$ and $25^{\text {th }}$ percentiles and the Gini coefficient. The table suggests three main findings. First, for all age groups there is marked inequality in wealth. This can be seen most clearly in the interquartile wealth ratio which shows how much the wealth of households at the $75^{\text {th }}$ percentile exceeds wealth of households at the $25^{\text {th }}$ percentile in the distribution. This ratio varies from a low of 3.6 for the oldest age group up to a whopping 437 for the youngest households. Households with reference persons aged under 25 years, however, are relatively uncommon and have many atypical characteristics and hence this figure should probably be ignored. Nevertheless, even for households where the reference person is aged 25 to 34 years the $75 / 25$ ratio is, at 11.2 , very

TABLE 6

Measures of the Distribution of Net Worth by Age Group

\begin{tabular}{|c|c|c|c|c|c|c|c|}
\hline \multirow[t]{2}{*}{$\begin{array}{l}\text { Age } \\
\text { (years) }\end{array}$} & \multicolumn{5}{|c|}{$\begin{array}{c}\text { Net worth percentile } \\
(\$ 000)\end{array}$} & \multirow{2}{*}{$\begin{array}{l}\text { Inter- } \\
\text { quartile } \\
\text { ratio: } \\
75 / 25\end{array}$} & \multirow[t]{2}{*}{$\begin{array}{l}\text { Gini } \\
\text { coeff. }\end{array}$} \\
\hline & $10^{\text {th }}$ & $25^{\text {th }}$ & $50^{\text {th }}$ & $75^{\text {th }}$ & 90th & & \\
\hline $15-24$ & -9 & 0 & 8 & 38 & 137 & 437.7 & 0.76 \\
\hline $25-34$ & 1 & 19 & 80 & 207 & 410 & 11.2 & 0.64 \\
\hline $35-44$ & 6 & 67 & 213 & 461 & 746 & 6.9 & 0.57 \\
\hline $45-54$ & 27 & 151 & 372 & 701 & 1180 & 4.6 & 0.54 \\
\hline $55-64$ & 15 & 156 & 426 & 837 & 1436 & 5.4 & 0.57 \\
\hline $65-74$ & 12 & 137 & 305 & 567 & 1080 & 4.1 & 0.57 \\
\hline $75+$ & 14 & 109 & 237 & 394 & 646 & 3.6 & 0.54 \\
\hline Total & 4 & 51 & 214 & 492 & 910 & 9.6 & 0.61 \\
\hline
\end{tabular}


large. Second, and as should be obvious from the figures just reported, the degree of within-cohort inequality generally declines with age. Third, with the exception of the very young households, which only account for a minority of all households, the level of inequality in the wealth distribution within age groups is less than the level of inequality within the entire population. In other words, a small part of the measured inequality in wealth is simply the result of the lifecycle.

\section{Accounting for Differences in Household Wealth}

\section{(i) Method}

We now turn to a consideration of the factors that help explain differences in wealth among Australian households by reporting the results of regressing household net worth against selected household characteristics. Two sets of regression results are given: one for households where the reference person is aged between 25 and 54 years and one for households where the reference person is aged 65 years or older. This is justified on the grounds that the factors influencing wealth accumulation are likely to be very different before and after retirement and most persons aged under 55 years are still in the labour force whereas most people aged 65 years or over have retired.

We thus began with two sub-samples comprising 4241 and 1300 cases, respectively. As usual, cases are deleted wherever data are missing on a relevant variable. As discussed at greater length below, three different specifications are estimated and the problem of missing data is only a serious issue for the third specification. This is because we included a number of variables in this specification that are constructed from answers to a leave-behind self-completion questionnaire (SCQ) which contains most of the attitudinal questions included in the HILDA Survey. The fact that it is self-administered means that there will be both some noncompliance -10 per cent of all individual respondents in wave 2 failed to return a completed SCQ - and higher rates of item non-response. As a consequence, the total number of cases used in the third specification is substantially smaller than in the other specifications; 3390 and 950 respectively.

Given the highly skewed nature of the wealth distribution, the dependent variable was specified as a log function. The coefficients can thus all be interpreted as percentage effects. This specification, however, did mean excluding all cases with 
negative wealth values. ${ }^{\text {xiv }}$ Cases with zero net worth were retained by arbitrarily recoding these cases to be worth $\$ 1$.

All equations were estimated with ordinary least squares.

\section{(ii) Explanatory Variables}

At the outset it needs to be noted that while some of the explanatory variables included in the analysis describe the household, most do not. Instead, most describe the household reference person. As already noted, variables were entered into the regressions in three steps which were seen as following the time sequence of most people's lives. At the first step we entered variables representing four types of characteristics that the household reference person was born with: sex, age, country of birth and parental occupation. Sex and country of birth are both represented by simple dummy variables. The sex dummy is, of course, a dichotomous variable. With country of birth, however, we distinguish not only between persons born in Australia and overseas, but among the latter, between persons born in the main English-speaking countries and those born in other countries. Age is a continuous variable and is specified as a quadratic in order to reflect the way wealth is accumulated and dissipated over the lifecycle. Finally, parental occupation status is measured using the ANU4 occupational status scale which assigns all occupations a score on a 0 to 100 scale (see Jones and McMillan 2000). Father's occupational status was taken if available, mother's if not. We hypothesized that households would be wealthier if the reference person was male and came from a high status background. Also that households headed by Australian born and people from other English-speaking countries would be wealthier than households headed by immigrants from non-Anglo backgrounds.

The second step involved the addition of education controls. Specifically, we included three dummy variables to divide the sample into four groups based on their highest educational qualification: a university degree, a trade qualification; completing high school (i.e., Year 12) and not completing high school. It is expected that education, by enhancing future earnings, would also tend to assist wealth accumulation.

The third step involved the addition of variables to capture current circumstances. Included here were variables representing household type, hours 
worked, household income, health, attitudes to savings and risk, and lifestyle. The household type variable distinguished between households based on whether or not the reference person was in a couple relationship and whether they had dependent children. The hypothesis was that couple households would be wealthier than oneperson households and that lone-parent households would be worst off.

The reference person's average weekly working hours and the $\log$ of the household's gross annual (financial year) income were included as was a dummy variable for current employment. We argue that current hours and employment are likely to reflect past employment patterns and hence should also predict wealth accumulation. Income is also expected to be positively correlated with wealth accumulation, though clearly there is an element of endogeneity involved in including income since for some households their wealth is a source of income. Nevertheless, for the large majority of non-retired households the primary source of income is paid work. Note that the income variable is constructed by first summing income components within individuals and then summing incomes of individual household members. To overcome problems associated with missing income components and partially responding households, we use the fully imputed estimates of household provided in the data release (see Watson 2004). Note further that in order to retain cases with zero or negative income, a dummy variable identifying such cases is included. This then allows us to recode the income for such cases to $\$ 1$.

Health is assessed using two sub-scales derived from the SF-36 Health Survey (Ware et al. 2000). Scored on a 0 to 100 scale, one measures general health, where higher scores indicate better subjective heath ( 5 items; alpha reliability $=0.82$ ), and the other mental health, where low scores reflect greater feelings of anxiety and depression ( 5 items; alpha reliability $=0.82$ ). We expect that households headed by people in good physical and mental health would be wealthier.

Self-reported measures of savings behaviour and risk aversion were also entered. We expected that saving would be associated with greater wealth while risk aversion would be associated with less wealth. Savings behaviour is represented by the inclusion of three dummy variables constructed from responses to a question asking respondents to describe their family's savings habits. Similarly, for risk aversion we included four dummy variables constructed from a question asking respondents to describe the amount of financial risk that they were willing to take. 
Since this question could not be answered by those who 'rarely have spare cash', one of the dummy variables identifies those unable to answer the question and is, almost by definition, closely associated with income

Finally, three lifestyle variables were added: number of cigarettes usually smoked per week, standard alcoholic drinks consumed per month, and frequency of exercise (times per week). We hypothesized that these lifestyle behaviours might be indicative of other personal characteristics that could influence wealth accumulation. For example, smoking might be symptomatic of a high rate of time preference (Becker and Murphy 1988), and thus be associated with lower levels of investment in the future. Further, the adverse health effects from smoking could be expected to reduce earnings thereby adversely affecting wealth accumulation. Certainly recent evidence exists that suggests that smoking is associated with a wage penalty (e.g., Levine, Gustafson and Velenchik 1997; van Ours 2004). In contrast, consumption of alcohol has typically been found to have positive effects on earnings, though such gains are often eliminated by heavy drinking (e.g., Barrett 2002). Given this, we enter alcohol consumption into the analysis in quadratic form.

Means and standard deviations for all explanatory variables and for both subsamples are provided in Appendix Table A.

The justification for entering the step 1 and step 2 variables before the others is straightforward. Step 1 includes only variables which describe characteristics one is born with and which are clearly temporally and thus causally prior to other variables. Step 2 includes only educational variables, and while it is true that some formal education is undertaken in later years, most people have completed this phase by early adulthood. Step 3 contains a diverse set of variables that we do not believe can be arranged in a plausible temporal or causal order. To give one example, household type variables (and marital status) could both cause and be caused by health conditions, by income and by attitudes and lifestyle. Similarly, one's health, attitudes and lifestyle could affect income, but the reverse is also true.

\section{(iii) Results}

Table 7 gives results for prime-age households and Table 8 gives parallel results for retirement age households. Focusing first on Table 7 and on step 1, we can see that the results are much as expected; the wealthiest households have male 
Australian-born 'heads' with parents from high status backgrounds, and wealth tends to peak at around age 55 years. Altogether these characteristics that household reference persons were born with accounted for 12.4 per cent of the variance in net household worth.

The second step in the analysis deals with education, which accounted for another 5.9 per cent of variance. So wealth depends somewhat on education (but rather less so than income does). Households headed by people with university degrees were on average 35 per cent wealthier than the reference group of people who completed Year 12, and people with less than Year 12 education were substantially less wealthy. A separate analysis showed that the education of the head's partner was also significantly related to total household wealth. ${ }^{\mathrm{xv}}$

Turning next to the results of step 3, household type was, as expected, very strongly related to net worth. Couples with dependent children or students were the wealthiest type of family followed by couples without dependents, and both groups were significantly wealthier than lone persons. Of course, such results are relatively uninteresting given that larger families and households are likely to require more wealth and income to meet material needs. In fact, when we transform the dependent variable into a measure of 'equivalised' net worth, by dividing total household net worth by the square root of the number of household members, the differences between couple households and lone person households disappears. ${ }^{\text {xvi }}$ What, however, is clear is that lone parents - nearly all women - were both the least wealthiest and the least well off.

Physical and mental health were moderately correlated with wealth $(\mathrm{r}=0.16$, $\mathrm{r}=0.20$ ) but nevertheless were statistically insignificant in this equation. A more subjective measure of health than the SF-36 scales used here, namely self-reported health on a scale from 'excellent' to 'poor', accounted for more variance, but is arguably a less valid measure of actual health condition.

Next we consider the effects of the reference person's weekly hours of work and the household's gross income. As expected, household income was strongly related to wealth. A separate analysis (not shown) indicated that both the reference person's income and his partner's income were significant separate contributors. The 
TABLE 7

Accounting for Differences in Wealth of Working-age Households - OLS regression coefficients (robust standard errors in parentheses)

\begin{tabular}{|c|c|c|c|c|c|c|}
\hline \multirow{2}{*}{$\begin{array}{l}\text { Explanatory variable } \\
\text { Male }\end{array}$} & \multicolumn{2}{|c|}{ Step 1} & \multicolumn{2}{|c|}{ Step 2} & \multicolumn{2}{|c|}{ Step 3} \\
\hline & $0.416^{* *}$ & $(0.06)$ & $0.422 * *$ & $(0.06)$ & $-0.254 * *$ & $(0.06)$ \\
\hline Age & $0.242 * *$ & $(0.04)$ & $0.245 * *$ & $(0.04)$ & $0.225 * *$ & $(0.04)$ \\
\hline Age squared (/100) & $-0.210 * *$ & $(0.05)$ & $-0.208 * *$ & $(0.05)$ & $-0.189 * *$ & $(0.05)$ \\
\hline \multicolumn{7}{|l|}{ Country of birth: } \\
\hline Overseas: MES & -0.101 & $(0.08)$ & $-0.159 *$ & $(0.08)$ & $-0.224 * *$ & $(0.08)$ \\
\hline Overseas: NES & $-0.243 * *$ & $(0.08)$ & $-0.329 * *$ & $(0.08)$ & $-0.268 * *$ & $(0.08)$ \\
\hline Parental status & $0.118 * *$ & $(0.01)$ & $0.052 * *$ & $(0.01)$ & 0.019 & $(0.01)$ \\
\hline \multicolumn{7}{|l|}{ Education: } \\
\hline Degree & & & $0.352 * *$ & $(0.08)$ & 0.025 & $(0.08)$ \\
\hline Trade qualification & & & $-0.194^{*}$ & $(0.08)$ & -0.043 & $(0.08)$ \\
\hline Less than Year 12 & & & $-1.057 * *$ & $(0.11)$ & $-0.526 * *$ & $(0.11)$ \\
\hline \multicolumn{7}{|l|}{ Household type: } \\
\hline Couple, no deps. & & & & & $0.351^{* *}$ & $(0.07)$ \\
\hline Couple w deps & & & & & $0.548 * *$ & $(0.07)$ \\
\hline Lone parent & & & & & $-0.743 * *$ & $(0.12)$ \\
\hline Working hours & & & & & $0.008 * *$ & $(0.00)$ \\
\hline Not working & & & & & $-0.346^{*}$ & $(0.15)$ \\
\hline Household income (ln) & & & & & $0.475^{* *}$ & $(0.06)$ \\
\hline Household income $\leq 0$ & & & & & $4.927 * *$ & $(0.94)$ \\
\hline Physical health & & & & & 0.020 & $(0.02)$ \\
\hline Mental health & & & & & 0.011 & $(0.02)$ \\
\hline \multicolumn{7}{|l|}{ Savings behaviour: } \\
\hline Saves but no plan & & & & & $0.243 * *$ & $(0.06)$ \\
\hline Saves other income & & & & & $0.472 * *$ & $(0.08)$ \\
\hline Saves regularly & & & & & $0.233 * *$ & $(0.07)$ \\
\hline \multicolumn{7}{|l|}{ Attitude to risk: } \\
\hline Average & & & & & $0.276^{* *}$ & $(0.06)$ \\
\hline Above average & & & & & $0.383^{* *}$ & $(0.09)$ \\
\hline Substantial & & & & & $0.531 * *$ & $(0.19)$ \\
\hline No spare cash & & & & & $-0.743 * *$ & $(0.09)$ \\
\hline Exercise frequency & & & & & -0.003 & $(0.01)$ \\
\hline Smoking (/100) & & & & & $-0.125 *$ & $(0.05)$ \\
\hline Drinking $(/ 100)$ & & & & & $0.263^{*}$ & $(0.11)$ \\
\hline Drinking sqred (/1000) & & & & & $-0.012 *$ & $(0.006)$ \\
\hline Constant & $4.933 * *$ & $(0.71)$ & $5.286^{* *}$ & $(0.69)$ & 0.150 & $(0.91)$ \\
\hline R-squared & \multicolumn{2}{|c|}{0.124} & \multicolumn{2}{|c|}{0.183} & \multicolumn{2}{|c|}{0.442} \\
\hline $\mathrm{F}$ & \multicolumn{2}{|c|}{$88.84 * *$} & \multicolumn{2}{|c|}{$88.16^{* *}$} & \multicolumn{2}{|c|}{$60.49 * *$} \\
\hline $\mathrm{N}$ & \multicolumn{2}{|c|}{4007} & \multicolumn{2}{|c|}{4007} & \multicolumn{2}{|c|}{3390} \\
\hline
\end{tabular}

Notes: 1. Dependent variable is the natural log of net household worth.

2. $* *$ and $*$ indicate statistical significance at the 1 and 5 per cent significance levels, respectively, in a two-tailed test.

2. Reference groups: country of birth $=$ Australia; education $=$ Year 12 ; household type $=$ lone person; savings behaviour $=$ does not save; attitude to risk = not willing to take any financial risks. 
other result shown, that if the reference person works longer hours the family is wealthier, is not as obvious as might seem. It actually suggests that, even after controlling for income, a family whose head works more actually saves more. Maybe that is why he/she works long hours.

Finally, we have the attitudinal and lifestyle variables. Self-reported savings was quite strongly positively related to wealth, while being risk averse was a clear negative. That said, we admit that the savings variable is quite strongly correlated with income and indeed it is possible that the results on the savings behaviour dummies are capturing nothing more than an income effect wherein income provides families with the capacity to save. Somewhat differently, attitudes to risk might be a response to wealth rather than a cause. With respect to lifestyle, the results suggest that smokers were less wealthy, drinkers were wealthier, but not the very heavy drinkers, and exercise made no difference. While we are not aware of any previous research that has investigated the associations between such variables and wealth, the results are in line with other research on the wage effects of smoking and drinking. Note, however, that the results presented here are at best indicative - no attempt for instance has been made to model the possible endogeneity of smoking and drinking status.

Table 8 reports the results of a similar analysis for households with heads over 65 and nearly all retired. Because of retirement, working hours are not included, and household income is also omitted because in most cases it would directly depend on, rather than contribute to wealth. The hypotheses to be tested remain the same, except that one would expect wealth to decline with age in retired households (rather than increase) as savings are run down. The results confirm this, with age inversely and significantly associated with age. Moreover, a linear specification is found to outperform the quadratic specification in this age group. Both persons from a relatively high social status and the Australian born again had greater wealth than immigrants, while education was again a factor - household reference persons with degrees had, on average, 64 per cent more wealth than retirees who completed Year 12 , who in turn were about 50 per cent $(1 /[1-0.348])$ wealthier than retirees who failed to complete high school. There was, however, sufficient variance for the latter difference not to be statistically significant. 


\section{TABLE 8}

Accounting for Differences in Wealth of Retirement-age Households - OLS regression coefficients (robust standard errors in parentheses)

\begin{tabular}{|c|c|c|c|c|c|c|}
\hline \multirow{2}{*}{$\begin{array}{l}\text { Explanatory variable } \\
\text { Male }\end{array}$} & \multicolumn{2}{|c|}{ Step 1} & \multicolumn{2}{|c|}{ Step 2} & \multicolumn{2}{|c|}{ Step 3} \\
\hline & $0.662 * *$ & $(0.11)$ & $0.580 * *$ & $(0.11)$ & 0.100 & $(0.11)$ \\
\hline Age & $0.024 * *$ & $(0.01)$ & 0.017 & $(0.01)$ & $-0.020^{*}$ & $(0.01)$ \\
\hline \multicolumn{7}{|l|}{ Country of birth: } \\
\hline Overseas: MES & $-0.613 * *$ & $(0.17)$ & $-0.667 * *$ & $(0.17)$ & $-0.620 * *$ & $(0.15)$ \\
\hline Overseas: NES & $-0.648 * *$ & $(0.21)$ & $-0.652 * *$ & $(0.21)$ & $-0.560 *$ & $(0.23)$ \\
\hline Parental status & $0.159 * *$ & $(0.03)$ & $0.121 * *$ & $(0.03)$ & $0.071^{*}$ & $(0.03)$ \\
\hline \multicolumn{7}{|l|}{ Education: } \\
\hline Degree & & & $0.642 *$ & $(0.26)$ & 0.168 & $(0.27)$ \\
\hline Trade qualification & & & 0.056 & $(0.22)$ & -0.096 & $(0.24)$ \\
\hline Less than Year 12 & & & -0.348 & $(0.22)$ & -0.242 & $(0.23)$ \\
\hline \multicolumn{7}{|l|}{ Household type: } \\
\hline Couple, no deps. & & & & & $0.593 * *$ & $(0.12)$ \\
\hline Couple w deps & & & & & $0.610^{*}$ & $(0.28)$ \\
\hline Lone parent & & & & & -0.242 & $(0.33)$ \\
\hline Physical health & & & & & -0.013 & $(0.03)$ \\
\hline Mental health & & & & & 0.056 & $(0.05)$ \\
\hline \multicolumn{7}{|l|}{ Savings behaviour: } \\
\hline Saves but no plan & & & & & 0.141 & $(0.16)$ \\
\hline Saves other income & & & & & $0.501 * *$ & $(0.18)$ \\
\hline Saves regularly & & & & & 0.253 & $(0.17)$ \\
\hline \multicolumn{7}{|l|}{ Attitude to risk: } \\
\hline Average & & & & & $0.578^{* *}$ & $(0.12)$ \\
\hline Above average & & & & & 0.735 & $(0.40)$ \\
\hline Substantial & & & & & 0.602 & $(0.91)$ \\
\hline No spare cash & & & & & $-1.136^{* *}$ & $(0.23)$ \\
\hline Exercise frequency & & & & & 0.005 & $(0.02)$ \\
\hline Smoking (/100) & & & & & $-0.312 *$ & $(0.15)$ \\
\hline Drinking $(/ 100)$ & & & & & $0.974 * *$ & $(0.24)$ \\
\hline Drinking sqred (/1000) & & & & & $-0.031 *$ & $(0.01)$ \\
\hline Constant & $13.04 * *$ & $(0.73)$ & $12.850 * *$ & $(0.77)$ & $12.629 * *$ & $(0.85)$ \\
\hline R-squared & \multicolumn{2}{|c|}{0.076} & \multicolumn{2}{|c|}{0.097} & \multicolumn{2}{|c|}{0.253} \\
\hline $\mathrm{F}$ & \multicolumn{2}{|c|}{$17.91 * *$} & \multicolumn{2}{|c|}{$15.34 * * *$} & \multirow{2}{*}{\multicolumn{2}{|c|}{$17.27 * *$}} \\
\hline $\mathrm{N}$ & \multicolumn{2}{|c|}{1240} & \multicolumn{2}{|c|}{1240} & & \\
\hline
\end{tabular}

Notes: 1. Dependent variable is the natural log of net household worth.

2. ** and * indicate statistical significance at the 1 and 5 per cent significance levels, respectively, in a two-tailed test.

3. Reference groups: country of birth $=$ Australia; education $=$ Year 12 ; household type $=$ lone person; savings behaviour $=$ does not save; attitude to risk $=$ not willing to take any financial risks. 
Perhaps surprisingly, step 3 of the analysis revealed few marked differences between retirees and working-age households. Again couple households retained a statistically significant wealth advantage over lone person households in retirement, but again this advantage, of about 60 per cent, could be regarded as substantively unimportant given that one person households require less wealth and income to meet material needs. And again neither of our physical nor mental health measures were related to wealth. Relationships between wealth and attitudinal variables were also similar in the retired as the working population; pro-saving attitudes were generally positively related and risk aversion negatively related to wealth. On the latter result, however, relatively few retirees indicated a willingness to take financial risks and hence the most substantive difference was between those who indicated an 'average' willingness and those not prepared to take any risks at all. And again we must admit the possibility that attitudes to risk may be a response to wealth, a possibility that seems especially plausible among retirees. Finally, the results suggest that the associations between smoking and drinking and wealth identified in the working-age sub-sample are also present in the retired sub-sample, though they do appear to be somewhat larger in magnitude.

\section{Discussion}

This paper has provided a snapshot of the net worth of Australian households in the last quarter of 2002 and confirmed what other studies using more indirect methods for deriving distributional estimates of household wealth have found - that wealth in Australia is very unequally distributed. Moreover, this inequality is not simply a function of the life cycle; even within age cohorts there is very pronounced concentration of wealth in the hands of relatively few.

It is important to be clear that while the survey from which the data used in this analysis has a panel design, the results reported are entirely cross-sectional in nature. They tell us very little about wealth dynamics. With future waves of the HILDA Survey, however, it should become possible to gain an understanding of such dynamics. Some might ask why bother investigating such issues; surely the stock of household wealth, unlike household income flows, is quite stable and just increases gradually over time. Indeed, at a conceptual level, stocks are more or less defined as 
being more stable than flows. Research in Sweden and the USA, however, has shown that, particularly in the former country, asset values have recently been quite volatile (Klevmarken et al. 2003). Relatedly, all Australian sources indicate that in the 1990s the increase in household wealth has considerably exceeded the rate of inflation, so it seems quite unlikely that an assumption of wealth stability is justified. The main assets held are in housing, equities and superannuation. Plainly, housing prices, particularly in the capital cities, have risen sharply in recent years and may now be starting to fall in real terms. Share prices, especially international shares, have also been volatile. Having risen rapidly for most of the 1990s, they fell 40 per cent in 2000-2002. The value of superannuation assets has also been volatile, since such assets are mainly dependent on share prices.

So it is probably mistaken to believe that household wealth is fairly stable. This means that it will be important to measure it and to assess the causes and consequences of change more frequently than has been done in the past. As the population ages, we need a closer understanding of the dynamics of wealth, particularly for those in the retirement and pre-retirement cohorts. 


\section{REFERENCES}

Ablett, J.R. (1983), The Distribution of Wealth and the Case for Annual Net Worth Taxation, CEDA Monograph no. M72, CEDA, Melbourne.

Association of Superannuation Funds of Australia (2004), How Much Do You Need To Have a Comfortable Standard of Living in Retirement? Association of Superannuation Funds of Australia.

Australian Bureau of Statistics [ABS] (2002), New Experimental Estimates of the Distribution of Australian Household Wealth (ABS cat. no. 1350.0), Australian Bureau of Statistics, Canberra.

Bækgaard, H. (1998a), 'The Distribution of Household Wealth in Australia: 1986 and 1993', NATSEM Discussion Paper no. 34, National Centre for Social and Economic Modelling, University of Canberra.

Bækgaard, H. (1998b), 'Simulating the Distribution of Household Wealth in Australia: New Estimates for 1986 and 1993', NATSEM Technical Paper no. 14, National Centre for Social and Economic Modelling, University of Canberra.

Barrett, G.F. (2002), 'The Effect of Alcohol Consumption on Earnings', The Economic Record 78, 79-96.

Becker, G.S. and Murphy, K.M. (1988), ‘A Theory of Rational Addiction', Journal of Political Economy 96, 675-701.

Dilnot, A.W. (1990), 'The Distribution and Composition of Personal Sector Wealth in Australia', Australian Economic Review, no. 89, 33-40.

Jones, F.L. and McMillan, J. (2000), 'Scoring Occupational Categories for Social Research: A Review of Current Practice, with Australian Examples', Work, Employment and Society 15, 539-63.

Juster, F.T., Smith J.P. and Stafford F. (1999), 'The Measurement and Structure of Household Wealth', Labour Economics 6, 253-76.

Kelly, S. (2001), 'Trends in Australian Wealth: New Estimates for the 1990s', Paper presented at the 30th Annual Conference of Economists, University of Western Australia, 26 September. 
Klevmarken, N.A., Lupton, J.P. and Stafford, F.P. (2003), 'Wealth Dynamics in the 1980s and 1990s', Journal of Human Resources 38, 322-53.

Levine, P.B., Gustafson, T.A. and Velenchik, A.D. (1997), 'More Bad News for Smokers? The Effects of Cigarette Smoking on Wages', Industrial and Labor Relations Review 50, 493-509.

Nevile, J.W. and Warren, N.A. (1984), 'How Much Do We Know About Wealth Distribution in Australia?', Australian Economic Review, no. 68, 23-33.

Northwood, K., Rawnsley, T. and Chen, L. (2002), 'Experimental Estimates of the Distribution of Household Wealth, Australia, 1994-2000', Working Papers in Econometrics and Applied Statistics, Working Paper No. 2002/1, Australian Bureau of Statistics, Canberra.

Parlett, N. and Rossiter, A. (2004), 'Residential Property Investors in Australia', Reserve Bank of Australia Bulletin, May, 52-56.

Piggott, J. (1984), 'The Distribution of Wealth in Australia - A Survey', The Economic Record 60, 252-265.

Podder, N. and Kakwani, N.C. (1976), 'Distribution of Wealth in Australia', Review of Income and Wealth 22, 75-92.

Reserve Bank of Australia [RBA] (2003), Productivity Commission Inquiry on First Home Ownership, Submission by the RBA, September.

Soltow, L. (1972), 'The Census of Wealth of Men in Australia in 1915 and in the United States in 1860 and 1870', Australian Economic History Review 12, $125-41$.

Van Ours, J.C. (2004), ‘A Pint a Day Raises a Man's Pay; but Smoking Blows that Gain Away', Journal of Health Economics, forthcoming.

Ware, J.E., Snow, K.K., Kosinski, M. and Gandek, B. (2000), SF-36 Health Survey: Manual and Interpretation Guide, QualityMetric Inc., Lincoln (RI).

Watson, N. (2004), 'Income and Wealth Imputation for Waves 1 and 2', HILDA Project Technical Paper Series No. 3/04, May, Melbourne Institute of Applied Economic and Social Research, University of Melbourne. 
Watson, N. and Wooden, M. (2002a), 'The Household, Income and Labour Dynamics in Australia (HILDA) Survey: Wave 1 Survey Methodology', HILDA Project Technical Paper Series No. 1/02, May (Revised September 2002), Melbourne Institute of Applied Economic and Social Research, University of Melbourne.

Watson, N. and Wooden, M. (2002b) 'Assessing the Quality of the HILDA Survey: Wave 1 Data', HILDA Project Technical Paper Series No. 4/02, October, Melbourne Institute of Applied Economic and Social Research, University of Melbourne.

Watson, N. and Wooden, M. (2004) 'Sample Attrition in the HILDA Survey', Australian Journal of Labour Economics 7, forthcoming.

Webster, E. (2000), 'The Growth of Enterprise Intangible Investment in Australia', Information Economics and Policy 12, 1-25. 
TABLE A

Means and Standard Deviations for Variables Used in Regression Analyses

\begin{tabular}{|c|c|c|c|c|c|c|}
\hline & \multicolumn{3}{|c|}{ Working age (25-54) } & \multicolumn{3}{|c|}{ Retirement age $(65+)$} \\
\hline & Mean & $\begin{array}{l}\text { Std. } \\
\text { dev. }\end{array}$ & $\mathrm{N}$ & Mean & $\begin{array}{l}\text { Std. } \\
\text { dev. }\end{array}$ & $\mathrm{N}$ \\
\hline \multicolumn{7}{|l|}{ Dependent variable } \\
\hline Ln net worth (\$) & 11.842 & 1.953 & 4060 & 12.0265 & 1.987 & 1290 \\
\hline \multicolumn{7}{|l|}{ Explanatory variables } \\
\hline Male & 0.627 & 0.484 & 4241 & 0.510 & 0.500 & 1300 \\
\hline Age & 40.010 & 8.121 & 4241 & 74.370 & 6.658 & 1300 \\
\hline \multicolumn{7}{|l|}{ Country of birth } \\
\hline Overseas: MES & 0.111 & 0.315 & 4241 & 0.152 & 0.359 & 1300 \\
\hline Overseas: NES & 0.124 & 0.330 & 4241 & 0.129 & 0.335 & 1300 \\
\hline Parental status & 4.336 & 2.185 & 4181 & 3.858 & 1.927 & 1248 \\
\hline \multicolumn{7}{|l|}{ Education } \\
\hline Degree & 0.265 & 0.441 & 4241 & 0.091 & 0.287 & 1300 \\
\hline Trade qualification & 0.425 & 0.494 & 4241 & 0.302 & 0.459 & 1300 \\
\hline Less than Year 12 & 0.220 & 0.414 & 4241 & 0.554 & 0.497 & 1300 \\
\hline \multicolumn{7}{|l|}{ Household type } \\
\hline Couple, no dependents & 0.294 & 0.456 & 4241 & 0.465 & 0.499 & 1300 \\
\hline Couple with dependents & 0.424 & 0.494 & 4241 & 0.004 & 0.062 & 1300 \\
\hline Lone parent & 0.110 & 0.313 & 4241 & 0.002 & 0.039 & 1300 \\
\hline Working hours & 36.905 & 20.065 & 4241 & & & \\
\hline Not working & 0.144 & 0.351 & 4241 & & & \\
\hline Ln household income (\$) & 10.861 & 0.930 & 4232 & & & \\
\hline Household income $\leq 0$ & 0.004 & 0.065 & 4241 & & & \\
\hline Physical health & 7.104 & 2.040 & 3709 & 6.146 & 2.177 & 1116 \\
\hline Mental health & 7.382 & 1.716 & 3745 & 7.713 & 1.671 & 1161 \\
\hline \multicolumn{7}{|l|}{ Savings behaviour } \\
\hline Saves but no plan & 0.374 & 0.484 & 3699 & 0.474 & 0.500 & 1119 \\
\hline Saves other income & 0.067 & 0.250 & 3699 & 0.097 & 0.297 & 1119 \\
\hline Saves regularly & 0.227 & 0.419 & 3699 & 0.207 & 0.406 & 1119 \\
\hline \multicolumn{7}{|l|}{ Attitude to risk } \\
\hline Substantial & 0.018 & 0.134 & 3701 & 0.002 & 0.042 & 1136 \\
\hline Above average & 0.091 & 0.288 & 3701 & 0.014 & 0.118 & 1136 \\
\hline Average & 0.370 & 0.483 & 3701 & 0.245 & 0.430 & 1136 \\
\hline No spare cash & 0.202 & 0.401 & 3701 & 0.159 & 0.366 & 1136 \\
\hline Exercise frequency (days / wk) & 2.874 & 2.336 & 3740 & 2.702 & 2.468 & 1169 \\
\hline Smoking (cigarettes / week) & 28.825 & 60.868 & 3719 & 7.378 & 31.660 & 1147 \\
\hline Drinking (std drinks / month) & 30.304 & 46.144 & 3725 & 25.371 & 45.060 & 1155 \\
\hline
\end{tabular}




\section{ENDNOTES}

i According to data published in the Reserve Bank of Australia Bulletin, March 2003 ('Household Debt: What the Data Show'), the household debt to income ratio rose from 56 per cent to 125 per cent over the decade to end 2002.

ii Podder and Kakwani (1976) reported a response rate of 50 per cent. Sample selection for this survey, however, was conducted in two stages, and this response rate was just the rate from the second stage. The true response rate is thus almost certainly much less.

iii For reviews of this literature, see Nevile and Warren (1984) and Piggott (1984).

iv The first Australian study to make use of this method was Ablett (1983), who used income data from the 1975-76 Household Expenditure Survey. His estimates, however, were restricted to financial assets.

v The 1915 Census data are not directly comparable with data from the later studies. Most importantly, the wealth component was restricted to adult males aged between 18 years and 60 years. Further, the Census was only concerned with the measurement of assets and not net worth.

vi For a discussion and analysis of attrition between waves 1 and 2 of the HILDA Survey, see Watson and Wooden (2004).

vii Note that while 31 per cent of households were unable to unwilling to provide all of the wealth data sought, this does not mean that they did not provide any data. Data on at least some component of wealth was collected from almost all households.

viii The imputations were undertaken by staff from the Reserve Bank of Australia. The only missing values not imputed were for those individuals who did not provide an interview but nevertheless were members of responding households. Thus, while total households assets and debts were fully imputed, as were all components collected at the household level, the estimates of superannuation, bank accounts, credit card debt, student debt and other personal debt are based entirely on members of households that completed the personal interview. For details of the imputation procedure used, see Watson (2004).

ix By comparison, the ABS suggests that dwellings (and land) only accounted for 46 per cent of total assets in 2000 (Northwood et al. 2000, p. 287). As already noted, this is a direct result of the much higher value for the estimated total dwelling stock obtained from the HILDA Survey data compared with the National Accounts. Interestingly, comparisons with estimates from other sources, including the Reserve Bank, Treasury, and the Real Estate Institute of Australia, suggest that it is the National Accounts estimate that is the outlier and not the HILDA Survey estimate (see Northwood et al. 2000, p. 53).

$x \quad$ For more a detailed analysis of residential property ownership using the HILDA Survey data, see Parlett and Rossiter (2004).

xi According to the HILDA Survey data from wave 2, 58 per cent of persons aged 15 years or older had at least one credit card, and 60 per cent of this group had paid off the entire balance when making their last payment (prior to survey). 
xii The ABS estimates for 2000 suggest a slightly lower level of concentration, with 43 per cent of wealth estimated to be held by the top wealth decile (Northwood et al 2000, p. 39).

xiii See the website of the Association of Superannuation Funds of Australia at www.asfa.asn.au, and especially the material under "A budget for a comfortable retirement".

xiv This resulted in the omission of 238 cases from the working-age sub-sample and just 15 cases from the retirement-age sub-sample.

${ }^{x v}$ If the reference person's partner had a degree the household was significantly wealthier. However, if the partner had not completed Year 12, this was unrelated to household wealth.

xvi It is not obvious though that equivalising in this way makes a lot of sense for all households; this depends on what wealth is used for. If, for example, wealth is used primarily to provide for retirement, then wealth requirements will be unrelated to the number of children in the household. 